\title{
CT findings in blast lung injury
}

\author{
Anastasia Oikonomou, ${ }^{1}$ Rennae Thiessen, ${ }^{2}$ Panos Prassopoulos ${ }^{1}$ \\ 1Department of Radiology, University Hospital of Alexandroupolis, Democritus University of Thrace, Alexandroupolis, Greece; \\ ${ }^{2}$ Department of Radiology, Vancouver General Hospital, Vancouver, British Columbia, Canada
}

Correspondence to Dr Anastasia Oikonomou, aoikonom@med.duth.gr

\section{DESCRIPTION}

A 16-year-old male suicide bomber committed suicide with grenade exploding in his hands. On scene, the patient was found unconscious with bilateral amputations above wrist, was blind from both eyes and had denudation of subcutaneous tissue of the anterior thoracic wall probably from shrapnel. He had Glascow coma scale 6, he was dyspnoeic, cyanotic, hypoxic (oxygen saturation $<75 \%$ ) with severe haemoptysis. The patient was immediately intubated and on admission chest radiograph revealed bilateral perihilar consolidations with blunted costophrenic angles. Chest CT revealed bilateral perihilar areas of consolidation with air-bronchogram extending subpleurally, mimicking a 'butterfly-wing' pattern (figures 1 and 2). Right hemopneumothorax and left haemothorax were seen, accompanied by retrosternal haematoma. Despite aggressive treatment that included carefully monitored fluid resuscitation with a pulmonary catheter and optimisation of patient's physiological respiratory status with pressure-limited, volumecontrolled ventilation with permissive hypercapnia, the patient eventually succumbed to his injuries 2 days later. Possible causes of death might have been pulmonary oedema or air-embolism. The lungs are at increased risk for primary blast injury due to extensive air-tissue surface and blast lung is the most common fatal injury among initial survivors of explosions. ${ }^{1}$ However, prompt diagnosis and aggressive treatment lowers inhospital death rate. Primary blast injuries are caused by the direct effect of a pressure wave on tissue caused by a sudden expansion of gas (explosive). Compression of air in front of the pressure wave leads to sudden increase in atmospheric pressure and temperature transmitted into the surrounding environment as a radially propagating shock wave known as 'blast wave'. ${ }^{2}$ Blast wave causes thoracic acceleration and propagates through lung parenchyma leading to immediate or delayed massive haemorrhage or contusions, pulmonary oedema, pneumothorax, barotrauma or arterial air-embolism. 'Blast lung syndrome' is characterised by the presence of respiratory distress, cough and hypoxia without penetrating or blunt thoracic injury. ${ }^{3}$ Chest radiograph and

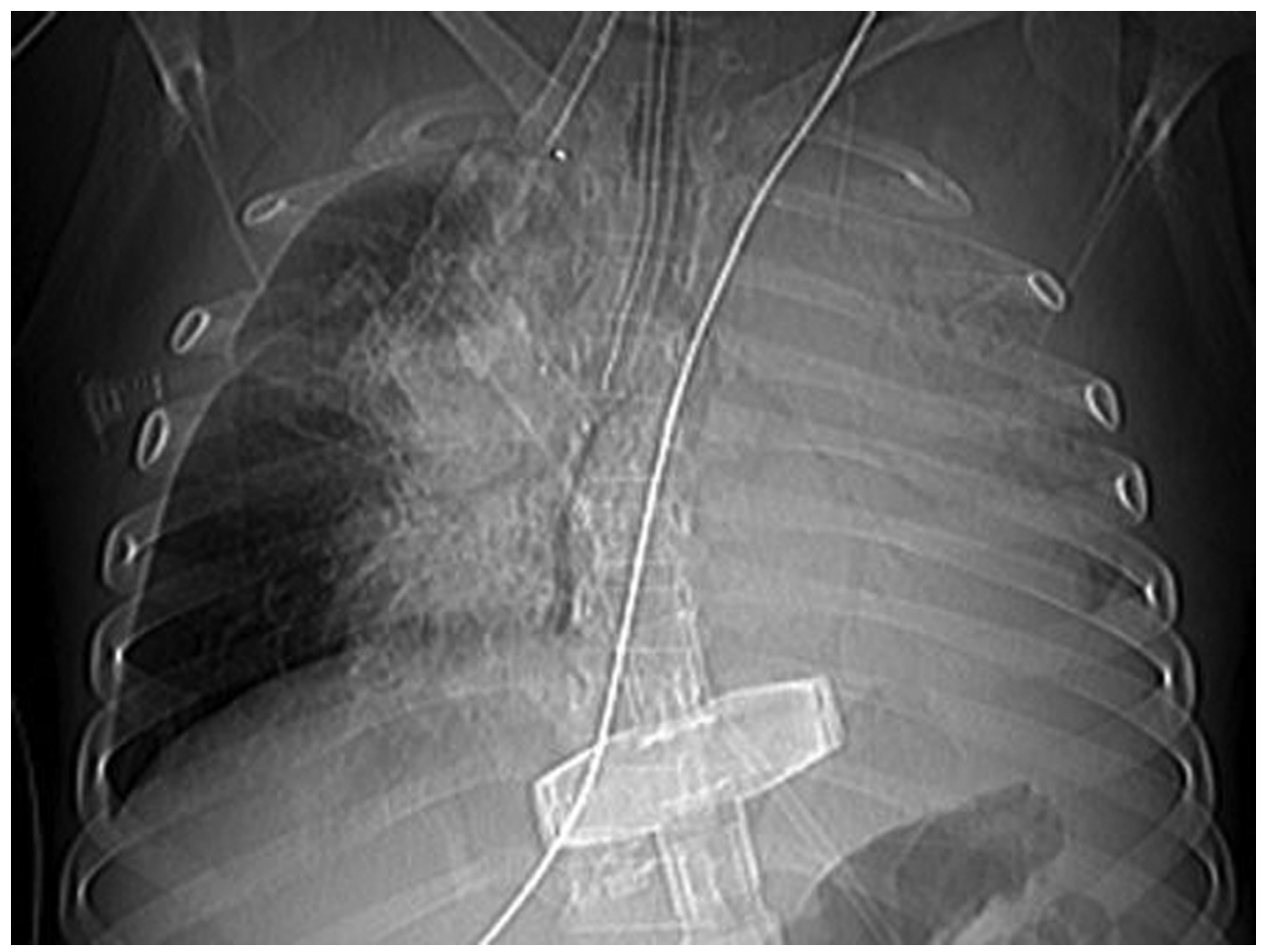

Figure 1 CT scanogram shows almost complete opacification of the left lung with presence of air-bronchogram and perihilar and lower lobe consolidation also with air-bronchogram in the right lung. 


\section{BMJ Case Reports}

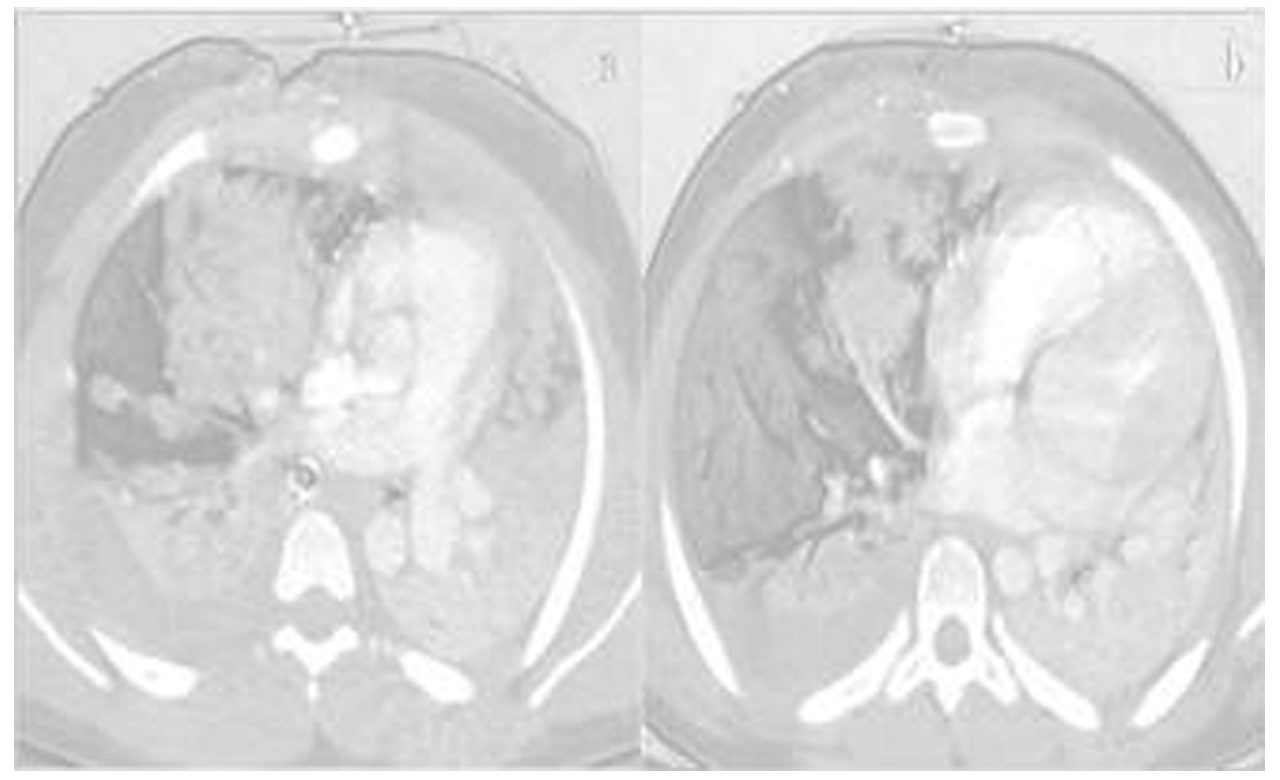

Figure $2(\mathrm{a}, \mathrm{b})$ Axial CT images at lung windowing, at the level of the middle lobe (a) and at the level of the lower lobes (b) show bilateral perihilar consolidations mimicking a 'butterfly' or 'bat-wing appearance', consistent with blast lung. The left lung is almost completely collapsed and there is left haemothorax and right hemopneumothorax. Denudation of the anterior chest wall is also noted (a).

CT will reveal the 'butterfly' or 'batwing pattern' representing bilateral, perihilar consolidation and ground-glass opacities. Since development of lung injury can be delayed, patients with clinical signs and normal chest radiograph should be observed for $6-8 \mathrm{~h}$ before discharge. ${ }^{1}$ In case of persistent symptomatology chest CT is strongly indicated as blast lung injury can be missed on chest radiograph. ${ }^{1}$

\section{Competing interests None.}

Patient consent Obtained

\section{REFERENCES}

1. Wolf SJ, Bebarta VS, Bonnett CJ, et al. Blast injuries. Lancet 2009;374:405-15.

2. Martí M, Parrón M, Baudraxler F, et al. Blast injuries from Madrid terrorist bombing attacks on March 11, 2004. Emerg Radiol 2006;13:113-22.

3. Ritenour AE, Baskin TW. Primary blast injury: update on diagnosis and treatment. Crit Care Med 2008;36(7 Suppl):S311-7.

This pdf has been created automatically from the final edited text and images.

Copyright 2012 BMJ Publishing Group. All rights reserved. For permission to reuse any of this content visit http://group.bmj.com/group/rights-licensing/permissions.

BMJ Case Report Fellows may re-use this article for personal use and teaching without any further permission.

Please cite this article as follows (you will need to access the article online to obtain the date of publication).

Oikonomou A, Thiessen R, Prassopoulos P. CT findings in blast lung injury. BMJ Case Reports 2012;10.1136/bcr.08.2011.4713, Published XXX

Become a Fellow of BMJ Case Reports today and you can:

- Submit as many cases as you like

- Enjoy fast sympathetic peer review and rapid publication of accepted articles

- Access all the published articles

- Re-use any of the published material for personal use and teaching without further permission

For information on Institutional Fellowships contact consortiasales@bmjgroup.com

Visit casereports.bmj.com for more articles like this and to become a Fellow

Keep up to date with all published cases by signing up for an alert (all we need is your email address) http://casereports.bmj.com/cgi/alerts/etoc 